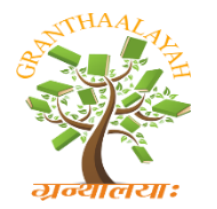

Science

\title{
LEVEL OF AWARENESS AND PARTICIPATION OF PANTAWID PAMILYANG PILIPINO PROGRAM BENEFICIARIES ON CLIMATE CHANGE ADAPTATION AND MITIGATION
}

\author{
Amerjaphil Louie A. Vidal *1, Anthony B. San Pedro ${ }^{2}$, Freyanne A. Redoble ${ }^{3}$, Mildred M. \\ Bermudez ${ }^{4}$ \\ ${ }^{* 1}$ Municipal Social Welfare and Development Office, Llanera, Philippines \\ ${ }^{2}$ Provincial Cooperative Entrepreneurship and Development Office, Nueva Ecija, Philippines \\ ${ }^{3}$ Office of the Vice Mayor, Maria Aurora, Philippines \\ ${ }^{4}$ Dr. Paulino J. Garcia Memorial Research and Medical Center, Cabanatuan City, Philippines
}

\begin{abstract}
This paper determined the level of awareness of Pantawid Pamilyang Pilipino Program (4Ps) beneficiaries on Climate Change and their level of participation in climate change adaptation and mitigation. The study is anchored on the Theory of Planned Behavior. The study utilized a descriptive survey method. The participants of the study are sixty-one (61) 4Ps Parent-Leaders from the twenty-two (22) barangays of Municipality of Llanera, Nueva Ecija. The results showed that 4Ps beneficiaries are aware of the effects of climate change but their participation to adapt and mitigate its effects are not always observed due to inadequate resources, technology and lack of support from the local government. The study showed the need to evaluate the 4Ps beneficiaries on the application of Family Development Session topics regarding Climate Change. The study may provide baseline data for the formulation of local policies and programs for participatory climate change adaptation and mitigation.
\end{abstract}

Keywords: Climate Change; Conditional Cash Transfer; Pantawid Pamilyang Pilipino Program; Family Development Session; Awareness; Participation.

Cite This Article: Amerjaphil Louie A. Vidal, Anthony B. San Pedro, Freyanne A. Redoble and Mildred M. Bermudez. (2018). "LEVEL OF AWARENESS AND PARTICIPATION OF PANTAWID PAMILYANG PILIPINO PROGRAM BENEFICIARIES ON CLIMATE CHANGE ADAPTATION AND MITIGATION." International Journal of Research - Granthaalayah, 6(7), 76-84. https://doi.org/10.29121/granthaalayah.v6.i7.2018.1286.

\section{Introduction}

Conditional Cash Transfer Programs are initiated by many countries to alleviate poverty. Conditional Cash Transfer is first initiated in Mexico and Brazil on which the main purpose is to render cash transfers to extremely poor families but with conditionality in terms of education and healthcare (Reyes and Tabuga, 2012). 
The Philippines has its own version of conditional cash transfer which is the Pantawid Pamilyang Pilipino Program or '4Ps' (Reyes, Taguba, Mina, and Asis, 2015). The Philippine government through the Department of Social Welfare Development (DSWD) executed the Pantawid Pamilyang Pilipino Program in 2008 which invests in the healthcare and education of poor eligible households and by improving the human capital. In order for the beneficiaries to receive the cash grant, there are some conditions set by the government which includes the compliance on health and education of the children beneficiaries as well as the attendance of the parents during Family Development Sessions (FDS). Family Development Sessions are conducted every month and different topics are being discussed by the Municipal Links. The topics discussed are related to health, education, disaster risk reduction and management, family values, and environmental management.

According to Fernandez and Olfindo (2011), the beneficiaries of Pantawid Pamilyang Pilipino Program had profited from the discussions during family development sessions in their communities. Family Development Session plays an important role on the lives of beneficiaries of Pantawid Pamilyang Pilipino Program in terms of increasing their awareness and preparedness on disaster risks. The level of responsiveness of the 4Ps beneficiaries improved. By being present during the Family Development Session, the views of 4Ps beneficiaries also changes towards the relevance of disaster preparedness. (Mangahas, Casimiro, and Gabriel, 2018).

Studies on the effectiveness of Family Development Session in relation to health (Pambid, 2017) as well as the perception of beneficiaries attending the Family Development Sessions module on risk reduction and management (Mangahas, Casimiro, and Gabriel, 2018) has been conducted.

FDS is the venue for the education of 4Ps beneficiaries regarding different issues arising in the community. One of the focuses of FDS regarding community is Climate Change. Climate Change, as defined by the National Aeronautics and Space Administration, is a change in the usual weather found in a place. The Philippines has taken different has taken different steps regarding Climate Change such as the passage of Republic Act No. 9729 also known as the Climate Change Act of 2009 mainstreaming climate change into government policy formulations. La Viña et. al. (2017) reported that the Philippines signed the Paris Agreement on Climate Change last 28 February 2017 with a commitment to reduce carbon emission by $70 \%$ by 2030 . Despite the different efforts of the Philippine government, education among the constituents is still deemed important.

Many studies regarding Pantawid Pamilyang Pilipino Progam and Family Development Session have been conducted but none of those studies have tackled the awareness of the 4Ps beneficiaries on climate change. Also, many studies on climate change have been conducted but none of those touched the people of the country (Philippines) who are living below the poverty line. This study would like to fill the 'gap in knowledge' on the how the Pantawid Pamilyang Pilipino Program through Family Development Sessions contributed on 4Ps beneficiaries in terms of their level of awareness on Climate Change and assessing their participation in Climate Change Adaptation and Mitigation. This study would also like to contribute to the growing studies on Climate Change. 


\subsection{Statement of the Problem}

This present study aims to determine the level of awareness of 4Ps beneficiaries on climate change and the level of their participation in Climate Change Adaptation and Mitigation. Specifically, this study aims to answer the following questions:

1) What are the topics discussed during Family Development Sessions related to Climate Change attended by the 4Ps beneficiaries?

2) What is the Level of Awareness of the Pantawid Pamilyang Pilipino Program (4Ps) beneficiaries on the Effects of Climate Change?

3) What is the Level of Participation of 4Ps beneficiaries on Climate Change Adaptation and Mitigation?

\section{Research Methodology}

\subsection{Study Locale}

The study locale is in Llanera, a fourth (4th) class municipality in the province of Nueva Ecija, Philippines. It has 22 barangays and population of 39,701 according to the 2015 survey of Philippine Statistics Authority

\subsection{Study Design}

The researcher utilized a descriptive survey method. The researcher adopted a five (5)-point Likert scale designed by Vagias (2006) in assessing the awareness of the participants and in assessing their participation in Climate Change Adaptation and Mitigation. The questions in the survey questionnaire are formulated and derived from the Department of Social Welfare and Development's modules on Family Development Sessions entitled (a) Guide and Map for Alert Filipino Family; (b) Community Preparedness; (c) I am as part of the community; and (d) Backyard Gardening. The results are interpreted based on the Average Weighted Mean with their corresponding statistical limit and descriptive equivalent. The researcher also gathered data through interviews and focus group discussions.

Table 1 Scoring Guide used to Interpret Survey Responses

\begin{tabular}{|l|l|l|}
\hline Average Weighted Mean & Descriptive Equivalent \\
\hline $1.00-1.80$ & Not all aware & Never \\
\hline $1.81-2.60$ & Slightly aware & Rarely \\
\hline $2.61-3.40$ & Somewhat aware & Sometimes \\
\hline $3.41-4.20$ & Moderately Aware & Often \\
\hline $4.21-5.00$ & Extremely aware & Always \\
\hline
\end{tabular}

\subsection{Respondents}

The researcher also used a purposive sampling technique to which the participants of this study are sixty-one (61) 4Ps Parent Leaders coming from the twenty-two (22) barangays of the Local Government Unit of Llanera, Nueva Ecija. The researcher requested for the names of participants on the Municipal Social Welfare and Development and asked permission to conduct the study. 
Municipal Links were also interviewed regarding on the topics they are discussing which are related to climate change.

Table 2: Distribution of Respondents per Barangay

\begin{tabular}{|l|l|l|l|l|l|}
\hline No. & Barangay & No. of Respondents & No. & Barangay & No. of Respondents \\
\hline 1 & A. Bonifacio Norte & 3 & 12 & Inanama & 3 \\
\hline 2 & A. Bonifacio Sur & 3 & 13 & Ligaya & 2 \\
\hline 3 & Bagumbayan & 4 & 14 & Mabini & 3 \\
\hline 4 & Bosque & 3 & 15 & Murcon & 3 \\
\hline 5 & Caridad Norte & 3 & 16 & Plaridel & 4 \\
\hline 6 & Caridad Sur & 2 & 17 & San Felipe & 6 \\
\hline 7 & Casile & 2 & 18 & San Nicolas & 1 \\
\hline 8 & Florida Blanca & 1 & 19 & San Vicente & 3 \\
\hline 9 & Gen. Luna & 3 & 20 & Sta. Barbara & 2 \\
\hline 10 & Gen. Ricarte & 3 & 21 & Victoria & 3 \\
\hline 11 & Gomez & 2 & 22 & Villa Veniegas & 2 \\
\hline Total Number of Participants $=61$ & \multicolumn{5}{|l}{} \\
\hline
\end{tabular}

\subsection{Theoretical Framework}

The study is anchored on the Theory of Planned Behavior by Ajzen (1991) as mentioned in the study of Skalik (2015). The theory states that the people's behavior to perform actions depends on some factors such as opportunities and resources. TPB, according to Hardeman, et al. (2002), is used to measure process and outcome variables and to predict intention and behavior, and less commonly to develop the intervention. This implies that awareness and participation of 4Ps beneficiaries on climate change will rely on the inputs such as Family Development Session as an area for the beneficiaries to acquire knowledge, their life experiences, and the availability of resources and technology.

\subsection{Conceptual Framework}

In order for the researcher to come up with the conclusion, the researcher critically analyzed the information gathered.

The input, process, and output as shown in the research paradigm represents the step by step procedure on how the researcher gathered information. The framework served as a guide that shows how the researcher successfully concluded the study.

Based on the gathered information and feedbacks of the participants through survey questionnaire using five (5)-point Likert Scale, interviews and focused group discussions, different insights are expected to arise. The researcher went through critical observations and analysis to conclude the level of awareness of 4Ps beneficiaries on the effects of climate change and their participation in climate change adaptation and mitigation. 


\section{INPUT}

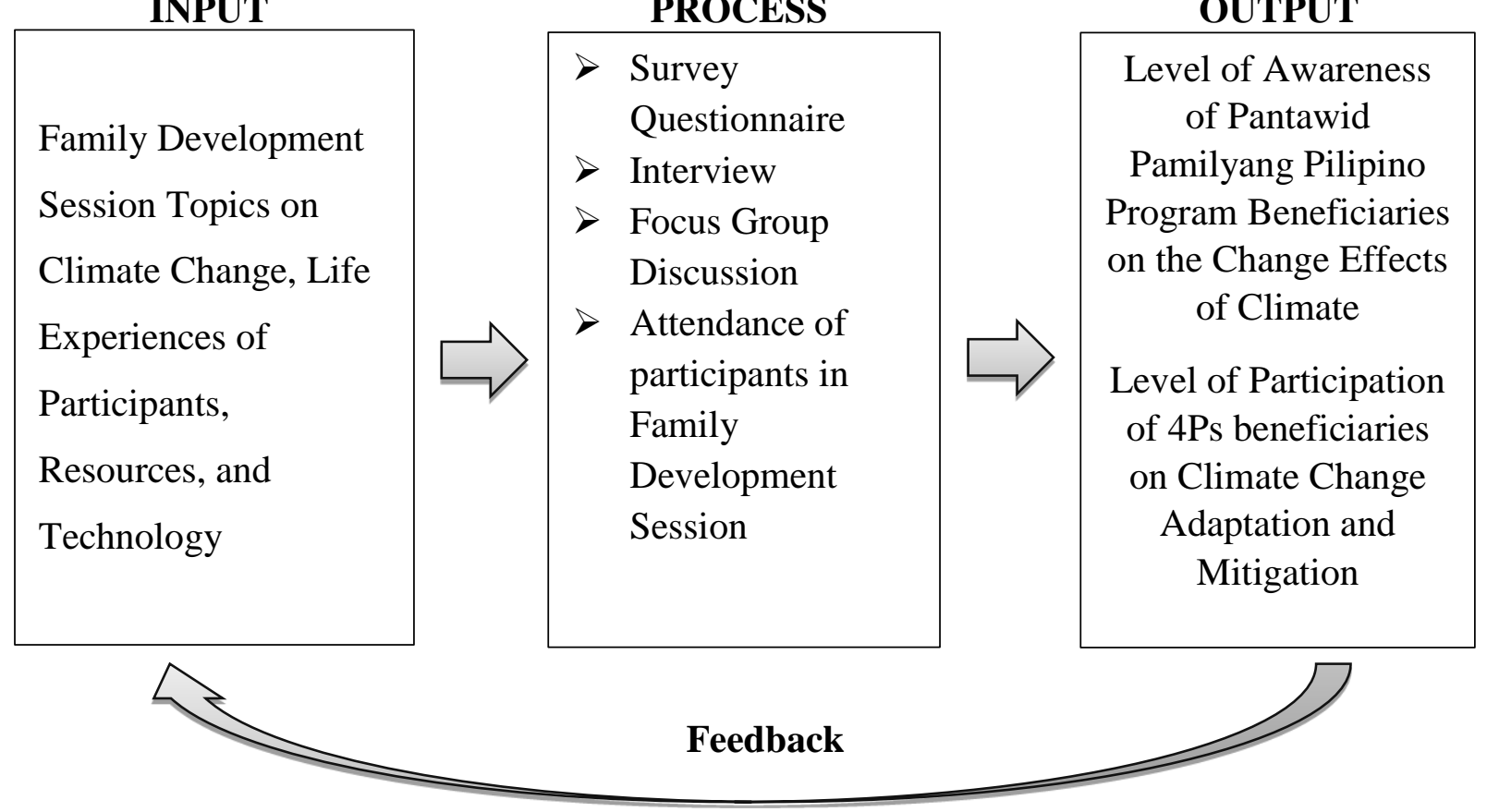

Figure 1: Research Paradigm

\section{OUTPUT}

of Pantawid

Pamilyang Pilipino

Program Beneficiaries

Change Effects of Climate

evel of Participation Ps beneficiaries on Climate Change daptation and Mitigation

\section{Results and Discussion}

This chapter presents the data gathered, the analysis and interpretations of the findings that are based on the stated problems.

Table 1 presents the topics related to climate change and the attendance of participants.

Table 1: Family Development Session Topics Related to Climate Change attended by the Pantawid Pamilyang Pilipino Program (4Ps) Beneficiaries N=61

\begin{tabular}{|l|l|l|}
\hline TOPICS & FREQUENCY & PERCENTAGE \\
\hline $\begin{array}{l}\text { Gabay at Mapa sa Listong Pamilyang Pilipino } \\
\text { (Guide and Map for Alert Filipino Family) }\end{array}$ & 61 & $100 \%$ \\
\hline $\begin{array}{l}\text { Paghahanda ng Komunidad } \\
\text { (Community Preparedness) }\end{array}$ & 61 & $100 \%$ \\
\hline $\begin{array}{l}\text { Ako bilang Parte ng Komunidad } \\
\text { (I am as part of the community) }\end{array}$ & 61 & $100 \%$ \\
\hline Backyard Gardening & 61 & $100 \%$ \\
\hline
\end{tabular}

Based on the interview conducted by the researcher on the Municipal Links, there are four topics discussed related to climate change, to wit: (1) Gabay at Mapa sa Listong Pamilyang Pilipino (Guidance and Map for Attentive Filipino Family); Paghahanda ng Komunidad (Community Preparedness); Ako bilang Parte ng Komunidad (I am as part of the community); and Backyard Gardening. The table shows that 61 participants have $100 \%$ attendance on the topics related to Climate Change. Due to the strict monitoring of their attendance during Family Development Sessions, it only reflected that beneficiaries of Pantawid Pamilyang Pilipino Program are very 
compliant with this conditionality. In order for them to receive the total amount of cash grant, a member of the household beneficiary should attend the Family Development Sessions which are scheduled every month. According to DSWD Social Protection Support Project Progress Report (2015), as cited in the Project Administration Manual (2015), compliance of 4Ps beneficiaries on FDS has been consistently high equivalent to $96 \%$ as of August 2015. Furthermore, Frufonga (2015) pointed out that FDS have a positive impact on the beneficiaries thus, $100 \%$ increased on their attendance was noted after three years of the implementation of 4Ps.

Table 2 presents the participants awareness of the issue of climate change and its effects, to wit;

Table 2: Level of Awareness of Pantawid Pamilyang Pilipino Program Beneficiaries on the Effects of Climate Change $\mathrm{N}=61$

\begin{tabular}{|l|l|l|}
\hline CRITERIA & AWM & DE \\
\hline Climate Change is a serious issue. & 3.85 & A \\
\hline I am aware that the temperature is rising and changing. & 4.45 & EA \\
\hline I am aware on the occurrence of Strong Typhoons/Cyclones. & 4.78 & EA \\
\hline I am aware of flooding. & 4.78 & EA \\
\hline I am aware that earthquakes are one of the effects of climate change. & 3.49 & A \\
\hline I am aware of Global Warming. & 3.59 & A \\
\hline I am aware of irregular rainfalls. & 4.44 & EA \\
\hline I am aware that the sea level rises. & 3.06 & SA \\
\hline
\end{tabular}

Table No. 2 shows that the participants are 'Extremely Aware' with the effects of Climate Change which includes Irregular Rainfalls having an average weighted mean of 4.44; Rising and Changing Temperature with an average weighted mean of 4.45; and Occurrence of Strong Typhoons/Cyclones and Flooding which ranks first having an average weighted mean of 4.75. Participants are 'Aware' of Earthquakes having an average weighted mean of 3.49 and Global Warming with an average weighted mean of 3.59. 'Somewhat Aware' is the answer of the participants on Sea Level Rise having an average weighted mean of 3.06, the lowest AWM for all the criteria. The Assessment Report on Awareness and Knowledge Level on Climate Change and Adaptation Practices of UNDP Cambodia (2012) also noted that hotter temperature, strong rain and wind, and irregular rainfalls are some of the visible effects of climate change. Human activities such as forest degradation or by cutting down of trees, or the used of high technology appliances such as air-conditioner and refrigerator also contribute to the climate change. Many people claimed that because of the effects of climate change, their lives are also affected since they suffer from health-related problems, water shortages, food insecurity for their crops was damaged, and lesser income. Moreover, Hope (2016) states that the people in Guyana have experienced different natural disasters such as flooding due to heavy rainfall, sea levels rising, and droughts. People are aware that deforestation, burning of fossil fuels and carbon emissions are contributing factors to climate change. It is also noted that damaged to property due to floods as well as loss of production on agricultural crops and livestock are results of the effects of climate change.

Table 3 presents the participation of 4 Ps beneficiaries in climate change adaptation and mitigation, to wit; 
Table 3: Participation of 4Ps Beneficiaries in Climate Change Adaptation and Mitigation N=61

\begin{tabular}{|l|l|l|}
\hline CRITERIA & AWM & DE \\
\hline I practice proper waste management and segregation. & 3.22 & Sometimes \\
\hline I am engaged in Tree Planting activities. & 2.90 & Rarely \\
\hline I walk instead of riding vehicle. & 2.93 & Rarely \\
\hline I do not burn plastics and other kinds of garbage & 3.31 & Sometimes \\
\hline $\begin{array}{l}\text { I participate in Climate Change Adaptation and Mitigation Program of } \\
\text { DSWD. }\end{array}$ & 1.65 & Never \\
\hline I am engaged in backyard gardening. & 3.59 & Often \\
\hline
\end{tabular}

Table 3 shows that participants are 'Often' engaged in Backyard Gardening with an average weighted mean of 3.59. The participants' response to Proper Waste Management and Segregation and not burning of plastics and other kinds of garbage is 'Sometimes' having an average weighted mean of 3.22 and 3.31 respectively. Participants are 'Rarely' engaged in Tree Planting Activities with an average weighted mean of 3.90 and also, participants 'Rarely' walk rather than riding vehicles such as motorcycle as one of the basic transport systems in the research locale. The lowest average weighted mean observed by the researcher is the participants' participation in Climate Change and Adaptation Program of the Department of Social Welfare and Development. Based on the focus group discussion, participants are very vocal that there is only limited opportunity for them to participate on DSWD's Climate Change Adaptation and Mitigation Program since the beneficiaries for the said program is being chosen by the local officials. According to The Asia Foundation (2012), Climate Change Perception Survey of on Dhaka, Bangladesh, only small proportion of the participants of the study are taking some individual participation and measures in mitigating climate change. Some of the activities the people do to mitigate climate change are planting of trees, vegetable and spice cultivation floating gardens and some of them are into migration.

\section{Conclusion}

The purpose of this study is to determine the level of awareness of 4Ps beneficiaries on the effects of climate change as well as the level of their participation in Climate Change Adaptation and Mitigation. Based on the above findings, the researcher, therefore, concluded that the topics discussed during Family Development Session are very helpful for the Pantawid Pamilyang Pilipino beneficiaries to gain more knowledge not only about Climate Change but also about the other problems and concerns arising in the community. Family Development Session is a very effective venue for new learnings for 4Ps beneficiaries since they are mandated to attend every session as a condition sets by the program.

In terms of the awareness of the 4Ps beneficiaries, they are all aware of the effects of climate change because of the learnings from FDS and life experiences. Although the beneficiaries are only somewhat aware with sea level rise since they live far away from coastal areas.

Furthermore, the participation of 4Ps beneficiaries is not always observed due to the limitedness of resources. Although some of the subjects of the study have knowledge with regards to climate change adaptation and mitigation, they are not able to put in into action due to the limitedness of resources, logistics, and technology as well. The 4Ps beneficiaries' participation in government 
initiated project to adapt and mitigate climate change is only minimal because of the lack of opportunity to participate. The participation of 4Ps beneficiaries in climate change adaptation and mitigation can be improved through injection of more learning and by having the support they need from the Local Government such as resources and technology.

\section{Recommendations}

Based on the findings of this study, the researcher arrived for the following recommendations:

- There should be additional or separate topics related to Climate change and every after Family Development Session, there should be an evaluation for the actual application of what they have learned.

- The Department of Social Welfare and Development should encourage the participation of 4Ps beneficiaries on Risk Resiliency Program - Climate Change Adaptation and Mitigation Cash for Work by adding a provision to the Memorandum of Agreement between the said agency and LGUs.

- Local Government Units and Local Social Welfare and Development Office should support the 4Ps beneficiaries by augmenting available resources and technology. This will empower them and will make them feel that their actions can help to mitigate the effects of climate change.

- The researcher recommends that future researchers conduct a study on the effectiveness of Family Development Session and its impact on the 4Ps beneficiaries. The assessment of the qualities of Municipal Links who conducts Family Development Sessions is also needed.

\section{References}

[1] Ajzen, I. (1991) Theory of Planned Behaviour. Amherst: University of Massachusetts.

[2] DSWD. Social Protection Support Project Report for the 1st Semester of 2015.Unpublished.

[3] Fernandez, L. and Olfindo. (2011) R. Overview of the Philippines' Conditional Cash Transfer Program; The Pantawid Pamilyang Pilipino Program (Pantawid Pamilya). 2011. The World Bank Group. Philippine Social Protection Note. May 2011. No. 2. Retrieved from http://siteresources.worldbank.org/INTPENSIONS/Resources/395443- 114253580

[4] Frufonga, R.F. (2015) The Pantawid Pamilyang Pilipino Program (4Ps) In Iloilo, Philippines: An Evaluation. Asia Pacific Journal of Multidisciplinary Research,Vol.3, No. 5, December 2015 Part II

[5] Hardeman W., Johnston M., Johnston D., Bonetti D., Wareham N., \& Kinmonth A.L. (2002) Application of the Theory of Planned Behaviour in Behaviour Change Interventions: A Systematic Review, Psychology \& Health, 17:2, 123-158, DOI: 10.1080/08870440290013644a

[6] Hope, S.A.A. (2016) Knowledge, Attitudes \& Practices Study On Climate Change Adaptation \& Mitigation In Guyana. UNDP. Retrieved from:

http://www.adaptationundp.org/sites/default/files/resources/climate_change_kap_survey_report_g uyana_0.pdf

[7] La Viña, A.G.M., Reyes, M.A., Labaria E.C., (2017, March 26). The Philippines, Climate Change, and the Paris Agreement. Manila Bulletin. Retrieved from:

http://faspselib.denr.gov.ph/sites/default/files//170326_Mla\%20Bull_The\%20Philippines\%2C\%2 0Climate\%20Change\%2C\%20and\%20the\%20Paris\%20Agreement_1.pdf 
[8] Mangahas, T.L.S., Casimiro, R.R. and Gabriel, A.G. (2018) Economically Challenged Women in Disaster Risk Management: Toward a Resilient Filipino Community.Open Journal of Ecology, 8, 42-56. https://doi.org/10.4236/oje.2018.81004

[9] Pambid, R.C. (2017) Level of Application of Family Development Session to Pantawid Pamilyang Pilipino Program (4Ps) Beneficiaries. PSU Journal of Education,Management and Social Sciences. Vol. 1 No. 1, pp.16-25.

[10] Project Administration Manual (2015). Republic of the Philippines: Social Protection Support Project. Retrieved from: www.adb.org/sites/default/files/project-document/180401/43407-014pam.pdf

[11] Republic Act No. 9729, Climate Change Act of 2009

[12] Reyes, C. M. and Tabuga, A. D. (2012) Conditional Cash Transfer Program in the Philippines: Is it reaching the extremely poor? Philippine Institute for Development Studies. Discussion Paper Series 2012-42 8399/2329423-1350588199143/8898265-1350588563122/philippines_cct.pdf

[13] Skalik. J. (2015) Climate Change Awareness and Attitudes Among Adolescents in the Czech Republic. Retrieved from: https://www.envigogika.cuni.cz/index.php/Envigogika/article/view/472

[14] The Asia Foundation. (2012) Climate Change Perception Survey. Dhaka, Bangladesh. Retrieved from: https://asiafoundation.org/resources/pdfs/ClimateChangeperceptionsurvey.pdf

[15] UNDP Cambodia. (2012) Assessment Report on Awareness and Knowledge Level on Climate Change and Adaptation Practices. Retreived from: http://www.kh.undp.org/content/dam/cambodia/docs/EnvEnergy/Awareness\%20and $\% 20$ Knowledge\%20Assessement\%20Report_Final.pdf

[16] Vagias, Wade M. (2006) Likert-type scale response anchors. Clemson International Institute for Tourism \& Research Development, Department of Parks, Recreation and Tourism Management. Clemson University. https://www.nasa.gov/audience/forstudents/k-4/stories/nasa-knows/what-isclimate-change-k4.html.

\footnotetext{
*Corresponding author.

E-mail address: anthonybasasanpedro @yahoo.com
} 